\title{
光学式非観血的連続的へマトクリットモニター CRIT-LINEの使用経験
}

\section{藍田將司 河田修一 鷹橋 浩 黒田 廣 金岡 健 ${ }^{11}$}

森本清貴 ${ }^{1)}$ 古田俊人 ${ }^{1)}$ 大場淳一1) 青木秀俊1) 村上忠司 ${ }^{11}$

要旨

今回我々は，透析用に開発されたJUS社製，光学式非観血的連続的へマトクリットモニター CRIT-LINE(CL)を人工心肺症例に使用した。また，COBE社製SAT/HCTモニターおよび, Baxter 社製0xySATモニターも同時使用し，それらの有用性について比較検討した。更に，CLは体外循 環血液量の変化をグラフにてリフルタイムに表示するため，その有用性についても梌討を加え た。比較は、ヘマトクリット $(\mathrm{Hct})$ ，静脈血酸素飽和土 $\left(\mathrm{SvO}_{2}\right)$ につい，各装置の表示值と同時 飞採血した実測值とを相関保数，回帰直線を求めて評価した。その結果， $\mathrm{Hct} ， \mathrm{SvO}_{2}$ は，各置 とも強い正の相関を示した。CL性静脈ラインに接続することができないため,リザーバーを介

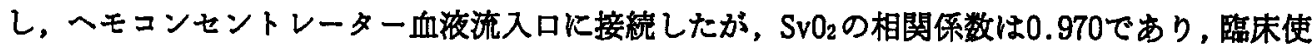
用上有用な装置であった。 また，体外循環血液量変化を表示するため，急激な血液希釉の対応 応や体液バランスの把㩧に有用であると考学られた。

Key words：CRIT-LINE, Hct， $\mathrm{SvO}_{2}$ ，体外循環血液量变化

\section{I 、はじめに}

近年，体外循環中のモニターとしてへマトク リット(以下，Hct)，血液ガス分析などを連続的に 測定できる装膡が数多く市販され，臨床使用され ている。

今回我々は，血液透析用に開発されたJMS社製，光 学式非観血的連続的へマトクリットモニターCRITLINE(以下，CL)を人工心肺症例に使用乙，COBE社 製SAT/HCTモニター(以下，SH)および, Baxter社慗 OxySATモニター(以下，OS) 当同時に使用したの でそれらの有用性について比較㭘討した。また， CLは体外循懪血液量变化率(以下，BV)をグラフに て表示するため，その有用性についてむ検討を加 えた。

\section{CLの仕様(図 1 )}

本装置は，高さ $13.3 \mathrm{~cm}$, 幅 $21.0 \mathrm{~cm}$ ，長さ29.5cm，

- 市立相川病院 臨床工学室

1) 同胸部外科

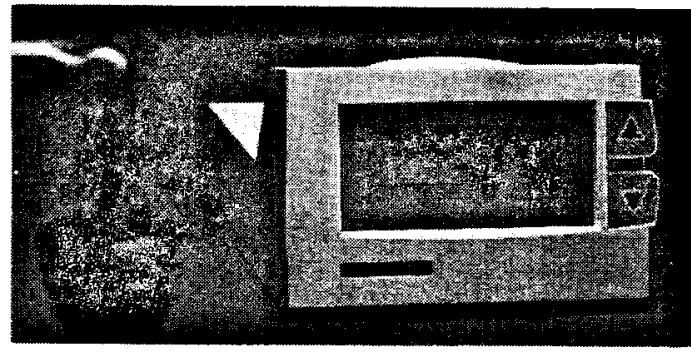

\begin{tabular}{|r|l|}
\hline サイズ & $13.3(\mathrm{H}) \times 21.0(\mathrm{~W}) \times$ \\
重量 & $29.5(\mathrm{D}) \mathrm{cm}$ \\
ディスプレイ & $2.3 \mathrm{~kg}$ \\
& 液晶ディスプレイ \\
パラメーター & $7(\mathrm{H}) \times 14.5(\mathrm{~W}) \mathrm{cm}$ \\
& ヘマトクリット \\
& 血液量変化 \\
& 酸素飽和度 \\
グラフィック表示 & 測定時間 \\
& 血液量変化プロ \\
& フィール \\
測定条件 & 血流量 : $50 \sim 500 \mathrm{m \ell} / \mathrm{min}$ \\
& 環境温度 : $13 \sim 38^{\circ} \mathrm{C}$ \\
\hline
\end{tabular}

图 1 CLの仕様 
重量2.3kgであり，測定時間，Hct括よび血液酸素 飽和度を測定表示し, Hctの変化よりBVをグラフに てリアルタイムに表示する装置で，それぞれ小数 点第 1 位まで表示する。また，BVはHetの変化よ り，次式から自動計算される。

$$
\mathrm{BV}(\%)=[[\mathrm{Hct}(\mathrm{star} t) / \text { 最新のHct }]-1] \times 100
$$

ディスポーザブルセル(以下，セル)は，透析用 に開発されているため,ダイアライザー血液流入 ロに接続するように設計されており，接続部の口 径は3/16インチである。

\section{III. 対象および方法}

対象は1996年10月から11月までに行われた開心 術の内, 各装置を同時使用した10症例で，疾患は 虚血性心疾患 (以下, IHD) 5 例, 弁膜疾患 (以下, VHD） 3 例，大動脈疾患 2 例であった。症例の体外 循環時間は174.9土102.3分, 大動脈遮断時間97.7 \pm 40.0 分, 最低直腸温 $26.4 \pm 6.0^{\circ} \mathrm{C}$ であった(表 1)。

体外循環は全例, 落差脱血にて行い, 人工肺は Jos t r a 社製膜型人工肺QUADROX,リザーバーはCOBE 社製SHセル内蔵のリザーバーHVRF3700を用いた。

各装置の測定部位は図 2 に示すように，SHはリ ザーバーに内蔵されている専用のセルを使用し， OSは脱血ラインに直接接続した。また，CLは脱血 ラインに直接接続することが困難であるため，リ ザーバーを介しへモコンセントレーター(以下，へ モコン)血液流入口へ接続した。

測定方法は人工心肺開始後30分ごとに採血を行 い, その実測值と，各装置の表示值とを比較した。
表 1 対象

\begin{tabular}{c|c}
\hline IHD & 5 例 \\
VHD & 3 例 \\
大動脈疾患 & 2例 \\
\hline \multicolumn{2}{|c}{$1996.10 .1 \sim 1996.11 .31$} \\
\hline
\end{tabular}

\begin{tabular}{c|c|c}
\hline 体外循環時間(min) & 大動脈遮断時間(min) & 最低直腸温( $\left.{ }^{(} \mathrm{C}\right)$ \\
\hline $174.9 \pm 102.3$ & $97.7 \pm 40.0$ & $26.4 \pm 6.0$ \\
\hline \multicolumn{2}{|c}{ (mean \pm S.D.) }
\end{tabular}

CLの条件はへモコンの血液流量を $200 \mathrm{~m} \ell / \mathrm{m}$ in し，人工心肺開始後，Hctが安定したと思われる 3 分後に電源を入れ測定を開始した。比較項目は， $\mathrm{CL}, \mathrm{SH}$ がHctおよび静脈血酸素飽和度(以下, $\mathrm{SvO}_{2}$ )， $\mathrm{OS}^{\circ} \mathrm{SvO}_{2}$ であり，それぞれの相関係数，回帰直線を 求めた。

Hctの比較測定機器は, COULTER STKS, Sv0 Radiome ter社製ガス分析装置ABL-505を用いた。

\section{N. 結 果}

\section{1. $\operatorname{Hct}$ (図 3)}

総検体数は37検体であり, HctはCL, 相関係数 0.942 , 回㷌直線 $\mathrm{y}=0.99 \mathrm{x}-0.20$, 平均誤差 3.27 $\%$ ，最大誤差 $18.00 \%$ 。SH，相関係数 0.876 , 回㷌直 線 $\mathrm{y}=0.76 \mathrm{x}-4.57$, 平均誤差 $6.42 \%$, 最大誤差 $15.18 \%$ であり，両装置とも強い正の相関を示し た。また，CLはリザバーを介して測定しているた め, Sucker, Vent血の影響を受けると考えられた が, 若干，相関係数ではCLで高值を示し俱差も少 なかった。

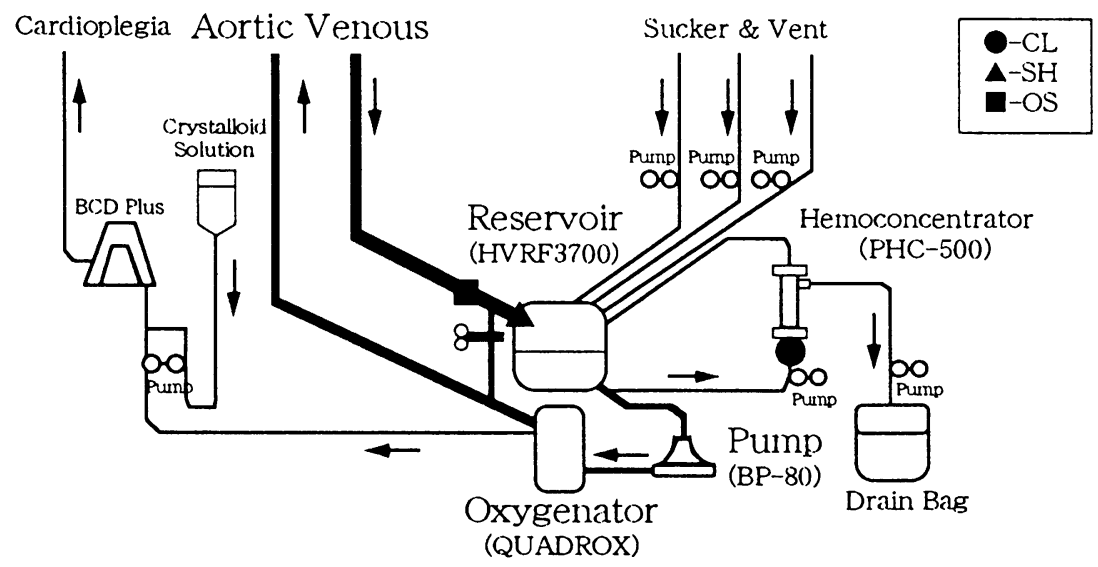

図2回路図 


\section{2. $\mathrm{SvO}_{2}$ (図 4)}

$\mathrm{SvO}_{2}$ はCL, 相関係数 0.970 , 回帰直線 $\mathrm{y}=1.05 \mathrm{x}-$ 4.28 , 平均誤差 $1.75 \%$, 最大誤差 $8.27 \%$ 。 SH, 相関 係数 0.957 , 回㷌直線 $\mathrm{y}=0.94 \mathrm{x}+6.76$, 平均誤差 $8.55 \%$, 最大誤差 $11.39 \%$ 。 $0 \mathrm{~S}$, 相関係数 0.974 , 回

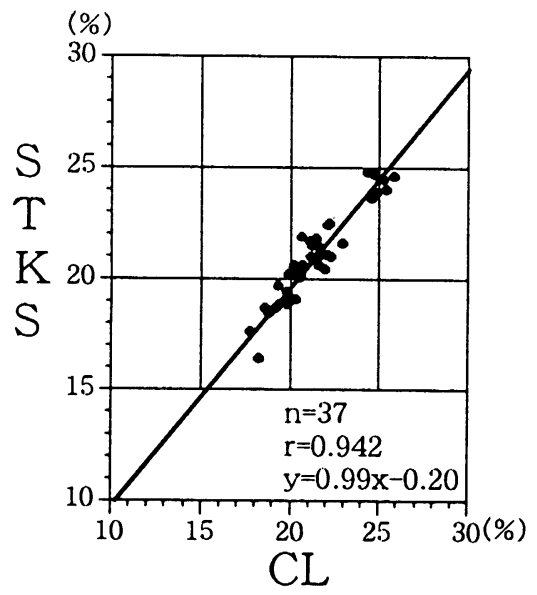

帰直線 $\mathrm{y}=0.82 \mathrm{x}+18.36$ 平均誤差 $4.84 \%$, 最大誤 差13.30\%であり，各装置とも強い正の相関を示し た。また，CLはリザバーを介して測定しているた め, Sucker, Vent血の影響を受けると考えられた が, $\mathrm{Sv0}_{2}$ は強い正の相関を示し誤差も少なかった。

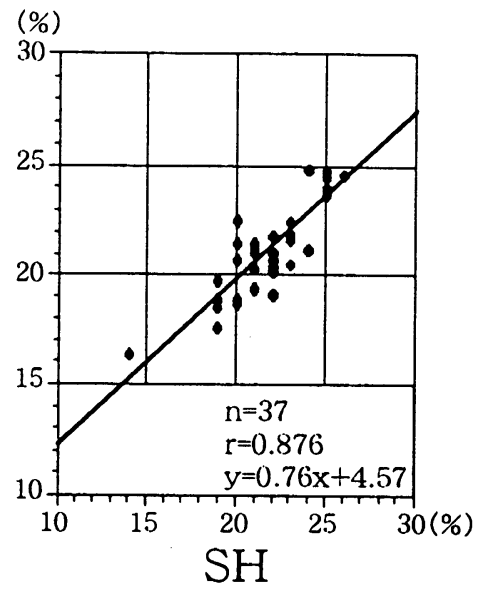

図 3 Hct

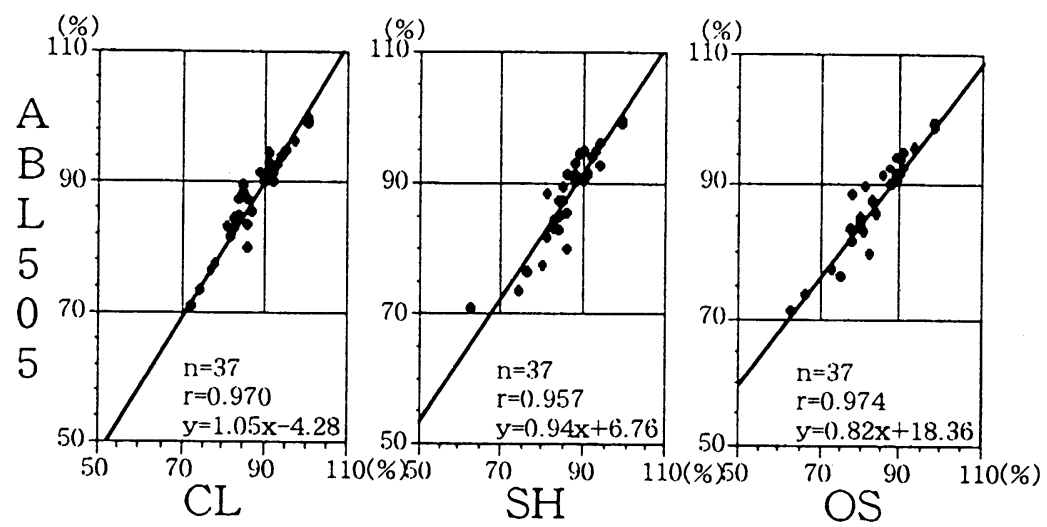

図 $4 \mathrm{SvO}_{2}$

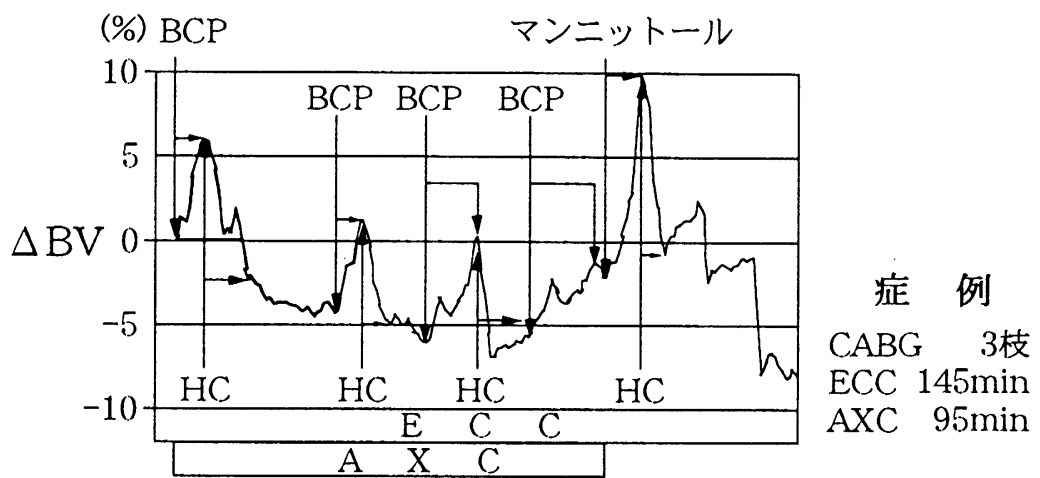

図 5 体循環血液量变化 
V.CLのモニター

因 5 はCABG 3 枝を施行した症例で，CLのBVをニ ンピュータに転送し作成したダラフである。体外 循環時間145分，大轨脈遮断時間95分，取低直得温 29.3Cであった。

体外循環を開始。大䡃脈遮断後 1 回目の心筋保 藤液を注入し，BVは希规により6.1\%まで上界し た。その後，へモコンにて除水を行い，BVはー2.3 へと下降した。2 回目，3回目の心觔保護液注入

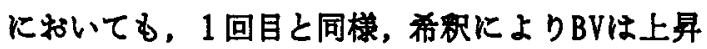
し，除水することによりBVは下降した。次に，大動 脈遮断解除時，マンニトールを注入したため，心 筋保護液注入時と同様，BVは上昇を示し，その後， 除水により下降した。この棣に，BVをグラフにて リフルタイムに表示するため，臨床使用上，有用 な機能を有する装膡であると考えられた。

図6は実祭のモニターで, BVのダラフの他に， 数値にて測定時間，Hct， BV，血旅酸素飽和度を表 示できる。

\section{CLの利点, 欠点(表 2)}

利点として，中+ブレーションが不要で，電源 を入れるのみで使用可能てあり，Hctの变化よりBV を自動計算し，グラフにてリナルタイムに表示す るため，急做な血液希积に迅速に対応でき，相対 的ではあるが，体液バランスを瞬時に把犎するこ とが可能である。また，セルのコストが非常に安 価である。
丧2CLの利点，火点

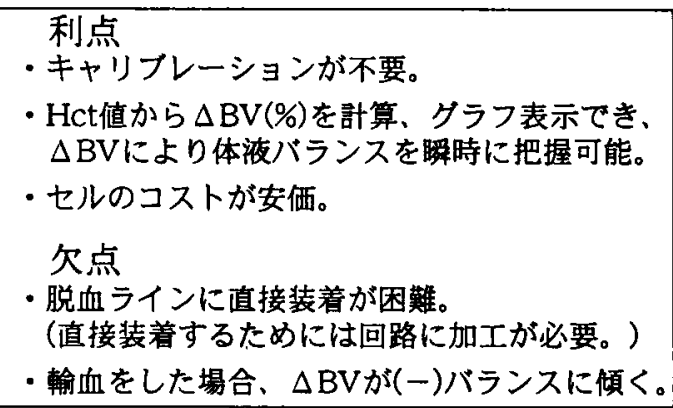

欠点として，セルはダイフライザー血液流入口 に接続するように設計されているため，脱血ライ ンに直接接続することが困難であり，直接接繶す るためには，回路を加工する必要がある。また，体

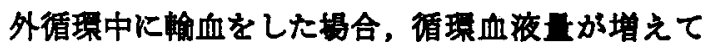
も，Hctが上界し，BVは下降するため，体液バラン スの指標としては困難となることなどが考えられ た。

\section{VI. 考察}

体外循謤の灌流の目的は，生体の䙶素需要を满 たすための必要酸素旦を送ることにある を知るらえで血液算出，血液ガス分析などは必要 不可欠な検查である。

今回我なは，血液透析用に開発されたCLを人工 心肺症例に使用し，SHおよびOS 同時使用し，比 較検討を行った。

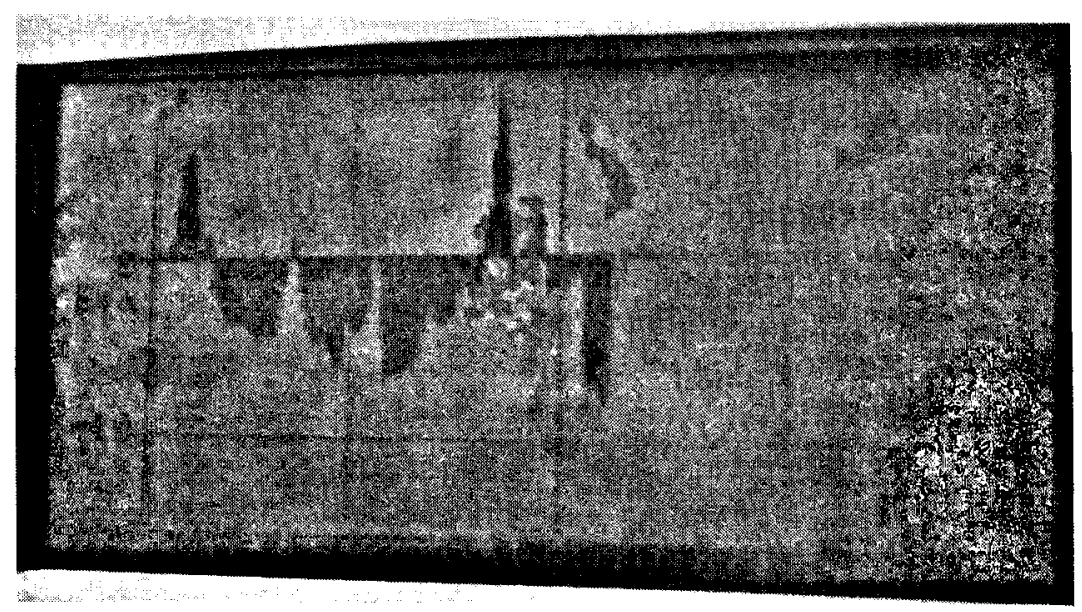

図 6 体狧桭血液量变化の実際 
その結果, CLのHctは相関係数0.942 と強い正の 相関を示し, 平均誤差は $3.27 \%$ と低值であった。 また，1検体のみ最大誤差 $18.00 \%$ となったため， この検体を除けば，より強い正の相関を得ること ができ，平均誤差もより低值を示すと考えられ た。CLのHctは小数点第 1 位まで表示するため, 少 量の希釈あるいは除水においても鋭敏に反映し, 他の機種よりも詳しい情報を得ることができると 考えられた。

更に, Hctより算出されるBVは他の機種には無い 機能であり，最近では血液透析中や人工心肺中の 体液管理に括ける有用性が報告されている3

BVはHetの変化より前述の式から自動計算され る。

例えば，Hctが20.0\%から20.1\%へと0.1\%上昇 を認めた場合，BV(\%) $=[[20.0 / 20.1] ー 1] \times 100$ となり，BVはー0.5\%を示すことになり，Hctが $20.0 \%$ か $21.0 \%$ へ 1.0\%上昇を認めた場合，BV はー4.8\%を示すことになる。このように，BVは， Hctの微妙な変化を鋭敏に反映し、リアルタイムに 表示すると同時に, グラフにて表示する。これに より，人工心肺中の心筋保護液注入やアイスス ラッシュなどによる急激な血液希釈，扣よび除水 による濃縮に迅速に反応するため，より筌密な体 液管理が可能となり，人工心肺中の体液バラン ス,ヘモコンによる除水量の指標として有用で あった。しかし，体外循環中は，水分の血管外への 移行, 輸血や回路外への出血等が起こる可能性が あり，BVが体液バランスの指標として必ずしも反 映しているとは限らず，困難となる可能性もあ り，体外循環バランスは，リザーバーレベルや圧 などの情報を総合的に把握し，判断する必要性が あると考えられた。そのため今後，BVと体外循環 バランスとの関係を検討していきたい。

$\mathrm{CL}$ の $\mathrm{SvO}_{2}$ は相関係数 0.970 , 回帰直線 $\mathrm{y}=1.05 \mathrm{x}$ -4.28 と Hct同様強い正の相関を示し, 平均䛠差も $1.75 \%$ と安定し，他の 2 機種と比較しても同等以 上の值を示した。また，CLはりザーバーを介して いるため, Sucker, Vent血の影響を受け，高值を示 すのではないかと薹虑したが，実測值との間に有 意差は認められなかった。しかし，CLをリザー バーを介して使用する以上, 症例により, $\mathrm{Hct}, \mathrm{SvO}_{2}$ はSucker, Vent血の影響を受ける可能性があるこ とを絶えず念頭に招かなければならない。
CLは，セルのコストが非常に安価であり，キャ リブレーションを必要とせず，電源を入れるのみ で測定時間, Hct，血液酸素飽和度を測定でき，簡 便な装置であった。しかし，血液透析用に開発さ れているため，ダイアライザー血液流入ロヘセル を接続するように設計されて括り，脱血ラインに 直接接続することは困難であり，当院ではリザー バーを介し，ヘモコン血液流入口ヘセルを接続し て使用した。当院のようにへモコン回路を静脈り ザーバー出口より分岐し，ポンプにて静脈リザー バーに返血する方式の施設では，本装置を有効に 使用することができるが，へモコン回路を動脈回 路に接続している施設では，Hct，BVの測定，判断 は可能であるがSv0 2 を測定できない欠点がある。

SHは専用リザーバーにセルが内蔵されているた め，セル自体のコストはかからない。またセルが 脱血を直接測定するといら利点がある。しかし， 指定された専用りザーバーを使用しなければなら ないといら問題点もある。SHのHctの相関係数は 0.876 , 回帰直線 $\mathrm{y}=0.76 \mathrm{x}-4.57$, 相関係数, 回 㷌直線ともにCLより不良であったが，生体の酸素 運搬能の指標として, 使用可能範囲と考えられ た。 $\mathrm{SvO}_{2}$ は, 相関係数 0.957 , 回帰直線 $\mathrm{y}=0.94 \mathrm{x}+$ 6.70 と強い正の相関を示した。 $\mathrm{SvO}_{2}$ は他の報告 ${ }^{5 \sim 7}$ よりも相関係数は高值を示して拈り，安定した值 であった。これは，脱血ラインに空気を巻き込む と表示值がばらつくが, 今回我々の測定では, 脱 血ラインに空気を巻き込まずに測定できたためと 考えられた。また，他の報告 ${ }^{5,6)}$ では比較測定機器 が同一機器でないため，その䛩差によるものも考 えられ，より良い結果となったと考えられた。

OSはセルを直接，脱血ラインに接続できるとい ら利点があるが，セル自体のコストがCLに比べる と非常に高価である。また，表示は $\mathrm{Sv}_{2}$ のみであ り，情報量の不足が感じられた。OSの結果は， $\mathrm{Sv}_{2}$ ， 相関係数 0.974 と非常に強い正の相関を示した。し かし，回帰直線は $\mathrm{y}=0.82 \mathrm{x}+18.36$ であり， $\mathrm{Sv}_{2}$ の 值が低ければ低いほど，本装置は実測值よりも高 値を表示する傾向にあると考えられた。

\section{VIII. 結 論}

(1) CL，SH，OSを人工心肺症例に使用し，それらの 有用性について比較検討した。

(2) 各装置のHct, $\mathrm{SvO}_{2}$ は, ともに高い相関を示し 
ておりり，臨床上有用な装置であると考えられ た。

(3) CLは人工心肺中の体液管理に有用であると考 えられた。

(4) 今後, 体外循環血液量変化と体外循環バラン スとの関係を検討していきたい。

\section{-参考文献}

1）草川 实 編：体外循環の実際. 初版, 東京, 南江 堂. 1991.p.62-70.

2) 草川 宽 編：体外循環の実際. 初版, 東京, 南江. 堂. 1991.p.133-140.

3）武田一人, 中本雅彦, 安永親生, ほか：ドライウエイ

卜設定における非観血的連続 Hematocrit Monitor 装置
(CRIT-LINE)の有用性について. 人工臟器, 26(3);704 $-707,1997$.

4）墌部まゆ2，川西秀樹，黒田真彦：人工肺中の連続 的循環血液量変化測定の有用性. 麻酔, 45(2)；189$193,1996$.

5) 安田 剛, 山崎隆文, 佐々木優二, ほか：COBE社製 「SAT/HCT モニター」の使用経臨. 体外循環技術, 19 (1);30-32,1993.

6）高橋幸志, 北本㥶永, 宫崎紀男：連続へマトクリッ 卜測定付き人工肺 CMS - CML ULTRA - VPCML の 使用経験．体外循環技術，19(1);33-34,1993.

7) 河田修一，涳田將司，橋 浩，ほか：膜型人工肺 OPTIMAの使用経験。体外循環技衍，22(1)：87-90， 1996.

\section{第20回 日本手術医学総会}

テーマ：手術医学のこれから

会場：パシフィコ横浜

会 期：平成10年10月16日(金)，17日(土)

\section{学術集会：}

1. 特別講演 三浦哲夫 司会 都築正和

2. 招請講演

3. シンポジウム

4. パネルディスカッション

5. 教育講演

6. 一般演題

7. サテライトシンポジウム ランチョンセミナー

会 長 釘 宮 豊 城 (順天堂大学医学部麻酔科学講座, 順天堂大学医学部附属順天堂医院手術部) 事務局長 西 村 欣 也 - 連絡先

2113-0033 東京都文京区本郷2-1-1 TEL.03-3813-3111 内線5271 FAX. 03-5689-3820 